\title{
Geochemical features and effects on deep-seated fluids during the May-June 2012 southern Po Valley seismic sequence
}

\author{
Francesco Italiano ${ }^{1}$, Marcello Liotta ${ }^{1}$, Mauro Martelli ${ }^{1}$, Giovanni Martinelli ${ }^{2}$, Riccardo Petrini ${ }^{3}$, \\ Anna Riggio ${ }^{4}$, Andrea Luca Rizzo ${ }^{1}$, Francesca Slejko ${ }^{3}$, Barbara Stenni ${ }^{3}$ \\ ${ }^{1}$ Istituto Nazionale di Geofisica e Vulcanologia, Sezione di Palermo, Palermo, Italy \\ ${ }^{2}$ Università di Trieste, Dipartimento di Matematica e Geoscienze (DMG), Trieste, Italy \\ ${ }^{3}$ Agenzia Regionale Prevenzione e Ambiente (ARPA) dell'Emilia Romagna, Sezione di Reggio Emilia, Reggio Emilia, Italy \\ ${ }^{4}$ Istituto Nazionale Oceanografia e Geofisica Sperimentale (OGS), Sgonico (Trieste), Italy
}

\section{Article history}

Received July 24, 2012; accepted August 22, 2012.

Subject classification:

Fluids, Geochemistry, Faults, Temporal changes.

\section{Introduction}

A periodic sampling of the groundwaters and dissolved and free gases in selected deep wells located in the area affected by the May-June 2012 southern Po Valley seismic sequence has provided insight into seismogenic-induced changes of the local aquifer systems. The results obtained show progressive changes in the fluid geochemistry, allowing it to be established that deep-seated fluids were mobilized during the seismic sequence and reached surface layers along faults and fractures, which generated significant geochemical anomalies.

The May-June 2012 seismic swarm (mainshock on May 29, 2012, M 5.8; 7 shocks $M>5$, about 200 events $3>M>5$ ) induced several modifications in the circulating fluids. This study reports the preliminary results obtained for the geochemical features of the waters and gases collected over the epicentral area from boreholes drilled at different depths, thus intercepting water and gases with different origins and circulation. The aim of the investigations was to improve our knowledge of the fluids circulating over the seismic area (e.g. origin, provenance, interactions, mixing of different components, temporal changes). This was achieved by collecting samples from both shallow and deep-drilled boreholes, and then, after the selection of the relevant sites, we looked for temporal changes with mid-to-long-term monitoring activity following a constant sampling rate. This allowed us to gain better insight into the relationships between the fluid circulation and the faulting activity. The sampling sites are listed in Table 1, along with the analytical results of the gas phase.

\section{Geo-hydrological background}

The Po sedimentary basin is filled by sediments of Alpine and Apennine origin. North-verging Apennine fronts that are buried under this cover overthrust the Padanian basement. Along with the north Apennine outcropping units, these buried structures represent a seismically active belt, where stresses connected in a complex way to the Neogene or earlier deformation history are still active [Boccaletti et al. 2011]. Plio-Quaternary stress field evaluations indicate the presence of a tectonic regime that is characterized by a $\mathrm{N}-\mathrm{NE}$ compressive axis, and average deformation rates that range from $4 \mathrm{~mm}$ /year to $7 \mathrm{~mm} /$ year have been measured in the area [Cenni et al. 2012]. The local tectonics drove the sedimentation processes, allowing the filling of the sedimentary basin by alternate layers of sand and clay [Ori 1993, and references therein]. Gravel is only present near the Apennine chain in the alluvial fan areas, while the bottom of the Quaternary sediments is located at depths of $100 \mathrm{~m}$ to $700 \mathrm{~m}$. These multilayered sequences constitute the Po aquifer system [Regione Emilia-Romagna and ENI-AGIP 1998].

In the part of the basin close to the Apennine chain (the belt of alluvial fans), aquifers are located in unsatured sediments and are subjected to seasonal recharge processes. North of this area, the hydrogeological features are quite different: fine sediments host confined and/or semiconfined aquifers that are characterized by low circulation velocities (10 m/year). Isotopic data of ${ }^{18} \mathrm{O} /{ }^{16} \mathrm{O}$ and ${ }^{2} \mathrm{D} /{ }^{1} \mathrm{H}$ indicate that the deep groundwaters in this area are of Alpine origin, while ${ }^{3} \mathrm{H},{ }^{14} \mathrm{C}$ and ${ }^{36} \mathrm{Cl}$ data indicate ages of 15,000 to 30,000 years [Martinelli et al. 1998, and references therein]. These ancient groundwaters are found mainly in sediments of Alpine origin, from $100 \mathrm{~m}$ in depth to the Quaternary basement [Dondi et al. 1982, Regione Emilia Romagna and ENIAGIP 1998]. Field data indicate that inside these sediments that are located at $100 \mathrm{~m}$ to $300 \mathrm{~m}$ in depth, the hydrostatic load increases linearly with depth, following a regular hydraulic gradient. On the other hand, at depths shallower than 
$50 \mathrm{~m}$, load fluctuations are observed in connection with rainfall and barometric pressure, although lenses of confined aquifers are known at shallow depth too. The above-mentioned features suggest that the meteorological effects on the piezometry of deep aquifers can be considered to be negligible in the part of the basin that borders the Po River in the north and the belt of the Apennine alluvial fans in the south [Albarello and Martinelli 1994, and references therein].

The chemical composition of the aquifers of the EmiliaRomagna Plain is largely due to the stratigraphy of the PlioQuaternary sedimentary successions, where the great prevalence of $\mathrm{CaHCO}_{3}$ groundwaters characterizes the plain at the foot of the Apennine range. The positive buried structure of the Mesozoic limestones, known as the Ferrara anticline, largely affects the composition of the shallow aquifers above it, which become of the $\mathrm{NaHCO}_{3}$ type all along the structure, due to the precipitation of calcite or to water-rock interaction processes with Al-silicates. The shape of this structure is clearly reflected by the chemical composition of the aquifers of the Emilia-Romagna Plain, where $\mathrm{NaHCO}_{3}$ type waters follow the WNW-ESE structural trend, as already established through seismic surveys [Pieri and Groppi 1981]. Saline, $\mathrm{NaCl}$, type waters are limited to the northeastern sector of the plain, and to the area north of Modena. They appear to be related to evaporitic material deposited in lagoonal areas north of the Ferrara anticline during the Pliocene [Conti et al. 2000] or to the uprising of marine brines trapped in Pliocenic layers. The O-H isotopic composition of the $\mathrm{NaCl}$ waters has a clear meteoric signature, and no inflows of present day seawater appear necessary to justify such a composition, although mixed phenomena between meteoric originated groundwaters and brines of the Pliocenic or pre-Pliocenic layers cannot be excluded. To better understand the role of deep-seated fluids during the MayJune southern Po Valley seismic swarm, a periodic sampling was carried out, including the groundwaters, dissolved gases, and free gases.

Six wells, which include phreatic (ca. 10-20 m deep) and deep groundwaters (boreholes drilled to depths $>100 \mathrm{~m}$; Table 1) were considered during the first sampling campaigns. Three of the six wells sampled, which represent deep groundwaters, were considered for regular periodic sampling. These wells are located in the municipalities of Mirandola (depth $190 \mathrm{~m}$, characterized by weak bubbling activity), Concordia [AGIP Mineraria 1977, Gorgoni and Tosatti 2004] (1,700 m deep AGIP well characterized by intense bubbling activity), and San Felice sul Panaro (190 m deep well, characterized by a little bubbling activity). The results from one of these (the Vallalta site) are shown in Table 1

The waters were sampled using PVC bottles, while the dissolved gases were sampled in $250-\mathrm{mL}$ glass vessels. When available, the bubbling gases were collected using an inverse funnel, driving the gas to a two-way sampling bottle. When free gas was not available, $240 \mathrm{~mL}$ water samples were collected in glass bottles sealed by a silicon rubber septa, using special pliers to extract the dissolved gas phase. All of the samples were collected, taking care to avoid even tiny bubbles, to prevent atmospheric contamination (details in Italiano et al. [2009]).

\section{3- Field work and laboratory results}

\subsection{Groundwaters}

The groundwaters were characterized by a circum-neutral $\mathrm{pH}$, variable ionic strengths (electrical conductivity in the range $1-20 \mathrm{mS} / \mathrm{cm}$ ) and a redox environment ranging from anoxic to slightly oxic. Based on their major constituent anions $\left(\mathrm{Cl}^{-}, \mathrm{SO}_{4}^{2-}, \mathrm{HCO}_{3}^{-}\right)$and cations $\left(\mathrm{Mg}^{2+}, \mathrm{Ca}^{2+}, \mathrm{Na}^{+}, \mathrm{K}^{+}\right)$, most of the waters belong to the $\mathrm{NaCl}$ hydrofacies, with the exception of the sample from Camposanto Menozzi station, which belongs to the $\mathrm{NaHCO}_{3} / \mathrm{Cl}$ water-type (Figure 1a). This is consistent with the saline signature reported for waters from wells in the northeastern sector of the Emilia-Romagna Plain and north of Modena [Martinelli et al. 1998].

$\mathrm{Na}$ and $\mathrm{Cl}$ show a linear correlation, with waters from the Mirandola site characterized by higher $\mathrm{Na}$ and $\mathrm{Cl}$ contents. On the basis of the molar concentrations, this trend deviates from a seawater dilution trend and from the 1:1 line as expected for halite dissolution. Waters appear to distribute along a progressive dilution pattern for saline $(65 \mathrm{~g} / \mathrm{l})$ waters found in fractured Mesozoic carbonates or in Pliocenic or pre-Pliocenic layers. This characterizes the structural high in the Modena-Ferrara low-plain area, which suggests possible admixing of a deep-seated component at different extents.

In terms of the oxygen and hydrogen isotopic compositions (Table 2), the collected waters deviate from the line of meteoric precipitation reported for Apennine catchments and the easternmost part of the Region (Ravenna Plain), while they plot close to the meteoric water line for northern Italy [Longinelli and Selmo 2003]. This indicates a meteoric origin, as already suggested by Martinelli et al. [1998] and a long circuit for the local groundwaters. However, waters from the Mirandola site appear to deviate slightly towards a freshwater-seawater mixing line, which supports the possible contribution of formation waters of marine origin. Preliminary $\mathrm{Sr}$ isotopic ratios have been measured on waters from the Mirandola, Concordia and San Felice sul Panaro sites. The Mirandola groundwaters sampled at different times overlap within the experimental error $\left({ }^{87} \mathrm{Sr} /{ }^{86} \mathrm{Sr}\right.$ in the range of 0.708793 to 0.708848 ). Slightly lower ${ }^{87} \mathrm{Sr} /{ }^{86} \mathrm{Sr}$ values were obtained for San Felice sul Panaro ${ }^{87} \mathrm{Sr} /{ }^{86} \mathrm{Sr}, 0.708762$ ), while the Concordia samples are characterized by a more radiogenic character $\left({ }^{87} \mathrm{Sr} /{ }^{86} \mathrm{Sr}, 0.709081\right)$. Assuming that the $\mathrm{Sr}-$ isotopic signature in the saline waters was not significantly altered by late-stage diagenetic processes, and that the high- 


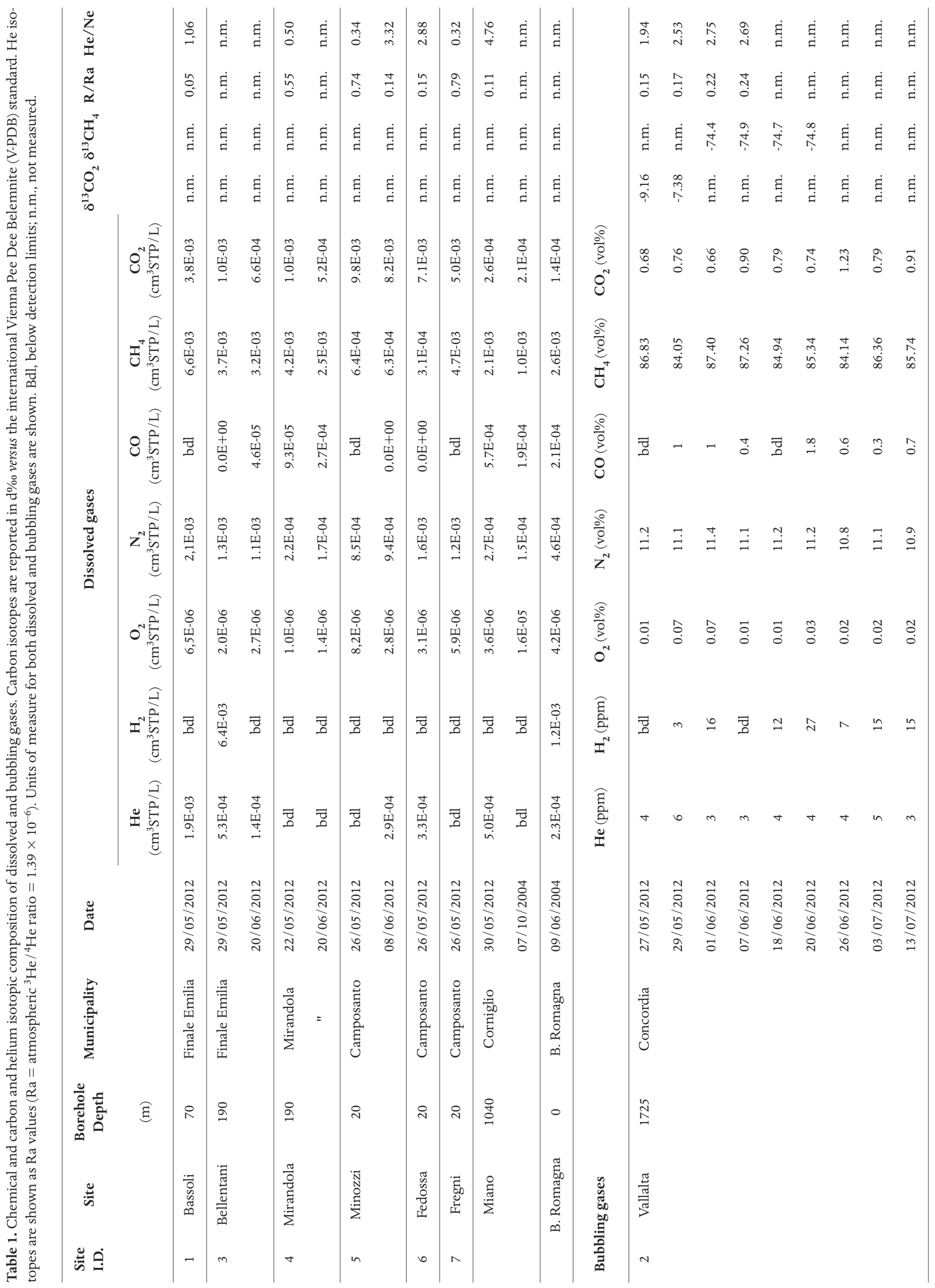




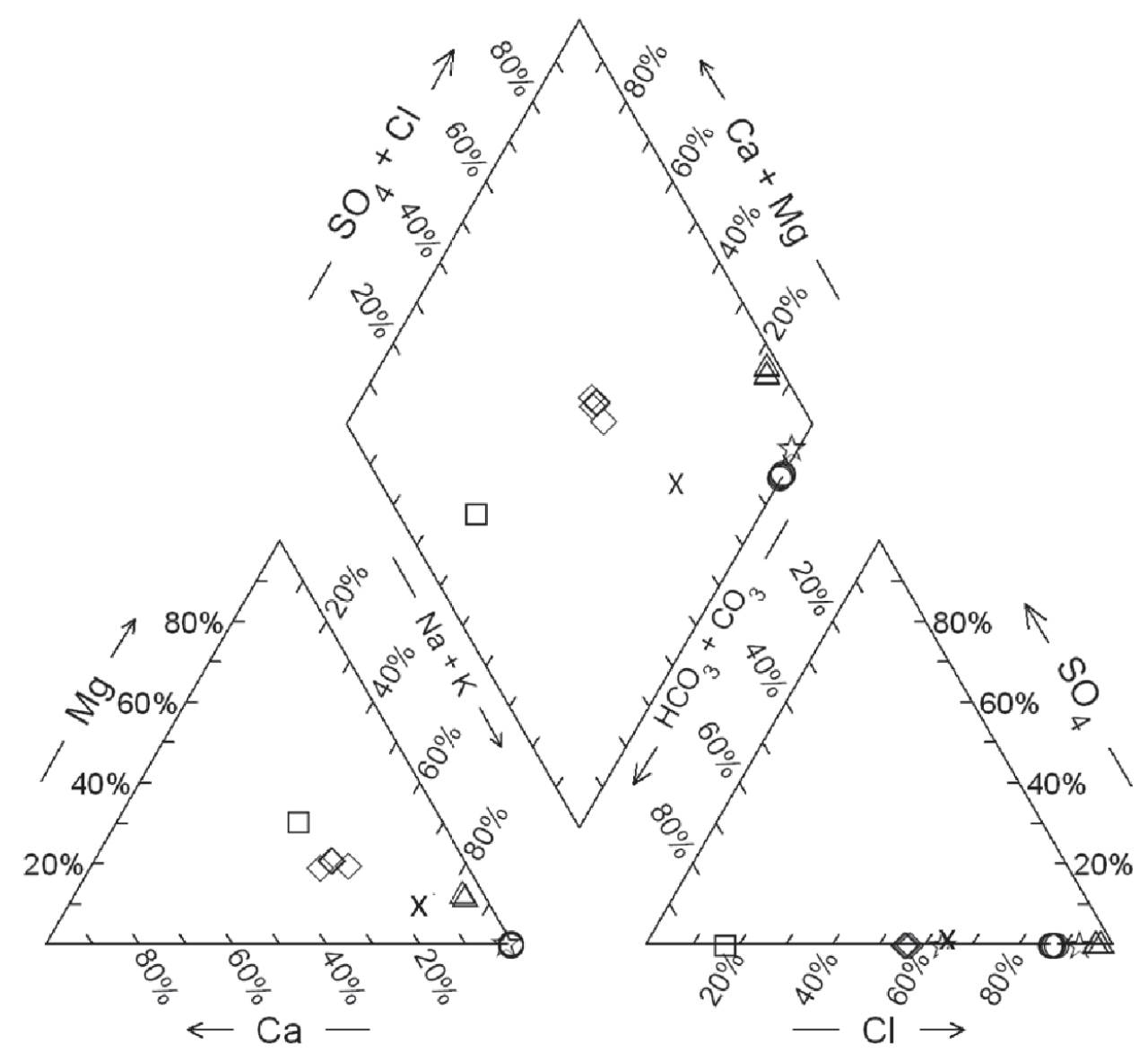

Figure 1a. Water geochemical features. Piper diagram for the water samples. Triangle, Mirandola; circle, Concordia; diamond, Bellentani; square, Menozzi; cross, Bassoli; star, Miano.

salinity component mostly contributed to the Sr budget in the waters studied, the isotopic composition of the Mirandola waters would correspond to a paleo-seawater component of Mio-Pliocene age.

\subsection{Gases}

The analytical results show that both bubbling and dissolved gases have low atmospheric contamination (Table 1). The oxygen content is negligible, and $\mathrm{CH}_{4}$ is always the main gas species. He is enriched in all of the gas samples, and particularly in the dissolved gases, where its concentration is greater than the equilibrium with air saturated water, by ca. 40-fold at the San Felice sul Panaro well, 50-fold at the Concordia well, and ca. 10-fold at Mirandola, which shows the deep provenance of the fluids feeding the selected sites.

Both dissolved and bubbling gases are plotted in the triangular diagram of Figure 1b, which shows the relative gas contents. It is worth noting the $\mathrm{CH}_{4}$ content, which is always the dominant species, includes the gases dissolved in shallow waters, as a consequence of diffuse $\mathrm{CH}_{4}$ degassing at a regional scale that can remove the atmospheric components from the recharged waters.

The carbon isotopic composition of $\mathrm{CH}_{4}\left(-79.7 \% 0<\delta^{13} \mathrm{C}<\right.$ $-74.4 \%$ ) collected at the deep boreholes (Table 1) highlights a biogenic origin for that methane from carbonate reduction. $\mathrm{CO}_{2}$ is always detectable in the bubbling gases, with a con- centration ranging between $0.66 \%$ and $0.9 \%$ at Concordia, ca. $1 \%$ at Massa Finalese, and $0.645 \%$ at San Felice sul Panaro. While the isotopic composition of $\mathrm{CO}_{2}$ from Massa Finalese is $-17 \%$, the gases at Concordia displayed more positive values, from $-9 \%$ o to $-7 \%$ (Table 1 ).

Considering together the information of the geochemical features of the gas phase, we argue that they originate from deep gas reservoirs, for which we exclude contributions from the mantle or mantle-derived sources, considering the isotopic ratio of $\mathrm{He}$ (in the range of 0.15-0.4 Ra). The significant amount of $\mathrm{He}$, which is mainly composed of ${ }^{4} \mathrm{He}$, originates from radioactive decay of the parent radioactive elements distributed in the thick sedimentary layers of the Po Plain, and concentrated in the hydrocarbon reservoirs responsible for the large release of $\mathrm{CH}_{4}$. High radon activity has never been detected, however, which includes the preliminary determinations carried out during the geochemical prospection. In contrast, temporal changes have been detected in other gas species, including $\mathrm{He}, \mathrm{CO}_{2}, \mathrm{~N}_{2}$ and $\mathrm{CH}_{4}$.

\section{Earthquake-induced variations}

The crustal deformative processes associated with the occurrence of the seismic sequence induced a squeezing of deep-seated groundwaters associated with brines of the Miocenic-Pliocenic geological structures of the Ferrara buried anticlines. 


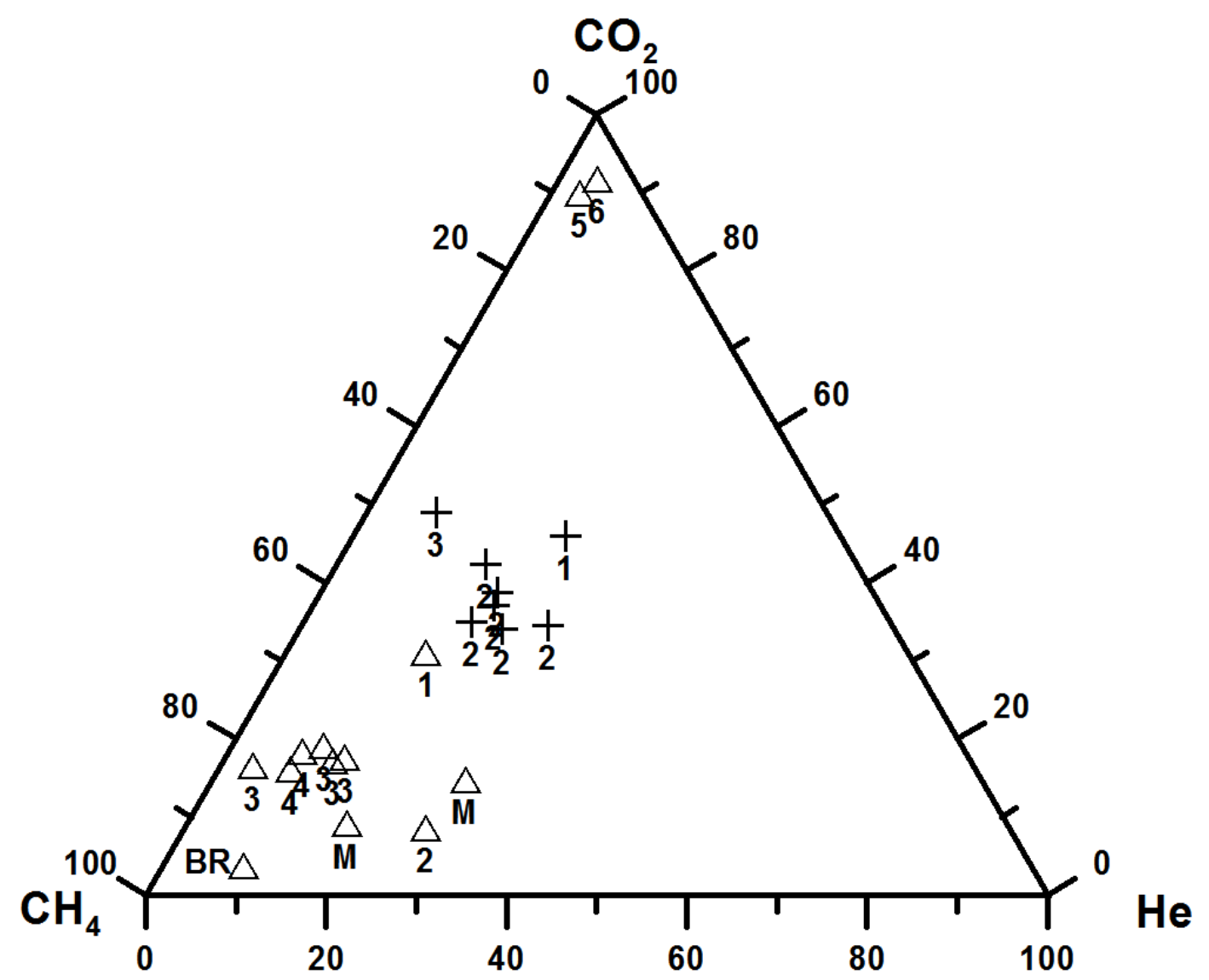

Figure 1b. Gas geochemical features. Triangular diagram showing the relative concentrations of $\mathrm{He}, \mathrm{CO}_{2}$ and $\mathrm{CH}_{4}$ for both bubbling (crosses) and dissolved (empty triangles) gases. Samples from two sites located far away from the epicentral area (M, Miano di Corniglio; BR, Bagno di Romagna) are shown for comparison. Sample I.D. as in Table 1.

\begin{tabular}{|c|c|c|c|}
\hline Site name & Date & $\delta^{18} \mathrm{O}$ & $\delta \mathrm{D}$ \\
\hline Bassoli & $29 / 05 / 2012$ & -10.03 & -68.29 \\
\hline \multirow[t]{3}{*}{ Bellentani } & $01 / 06 / 2012$ & -10.79 & -74.93 \\
\hline & $07 / 06 / 2012$ & -10.81 & -74.63 \\
\hline & $29 / 05 / 2012$ & -10.81 & -74.09 \\
\hline Minozzi & $08 / 06 / 2012$ & -8.42 & -54.55 \\
\hline \multirow[t]{3}{*}{ Mirandola } & $29 / 05 / 2012$ & -7.71 & -52.99 \\
\hline & $01 / 06 / 2012$ & -8.12 & -55.73 \\
\hline & $07 / 06 / 2012$ & -8.68 & -60.29 \\
\hline \multirow[t]{3}{*}{ Vallalta } & $29 / 05 / 2012$ & -10.68 & -73.81 \\
\hline & $01 / 06 / 2012$ & -10.70 & -74.96 \\
\hline & $07 / 06 / 2012$ & -10.69 & -74.99 \\
\hline
\end{tabular}

Table 2. Isotopic composition of stable isotopes $\left(\mathrm{O}_{2}\right.$ and deuterium) for some waters collected during the seismic crisis. Data in d\%o versus Standard Mean Ocean Water (SMOW) international standard.
In the same sampling sites, and in particular during the month of May 2012, analysis of the dissolved gases and free gases detected a deep component that was characterized by high $\mathrm{He}$ concentrations, as above the atmospheric contribution, and by ${ }^{13} \mathrm{C}$ linked to deep geological layers. In coincidence with the May 29, 2012, M 5.8 event, the $\mathrm{CH}_{4}$ concentration in the bubbling gases from the deep well of the Vallalta site dropped sharply, with an increase in $\mathrm{CO}_{2}$ (Figure 2a). The $\mathrm{CO}_{2}$-rich component is also the main carrier for $\mathrm{He}$; thus, considering the radiogenic origin for the He component, we argue that the deep crustal component is represented by a $\mathrm{CH}_{4}$-dominated ( $>80 \%$ by volume), $\mathrm{CO}_{2}$-rich ( $1 \%$ to $5 \%$ by volume) gas phase. After the occurrence of the main earthquakes, the gas composition underwent modifications, which were probably due to the long-term seismicity of the area. A behavior marked by a slow recovery of the former equilibrium conditions will help to define the background level for the area in terms of natural venting of deep and shallow components and their mixing proportions. We expect that the general behavior might show similar effects as those already observed in several sites around the epicentral area of the 1997-98 Umbria seismic sequence [Italiano et al. 2004]

Preliminary speciation calculations at the Concordia site indicate that the waters underwent an abrupt calcite undersaturation pattern, followed by a trend towards new saturation 




a

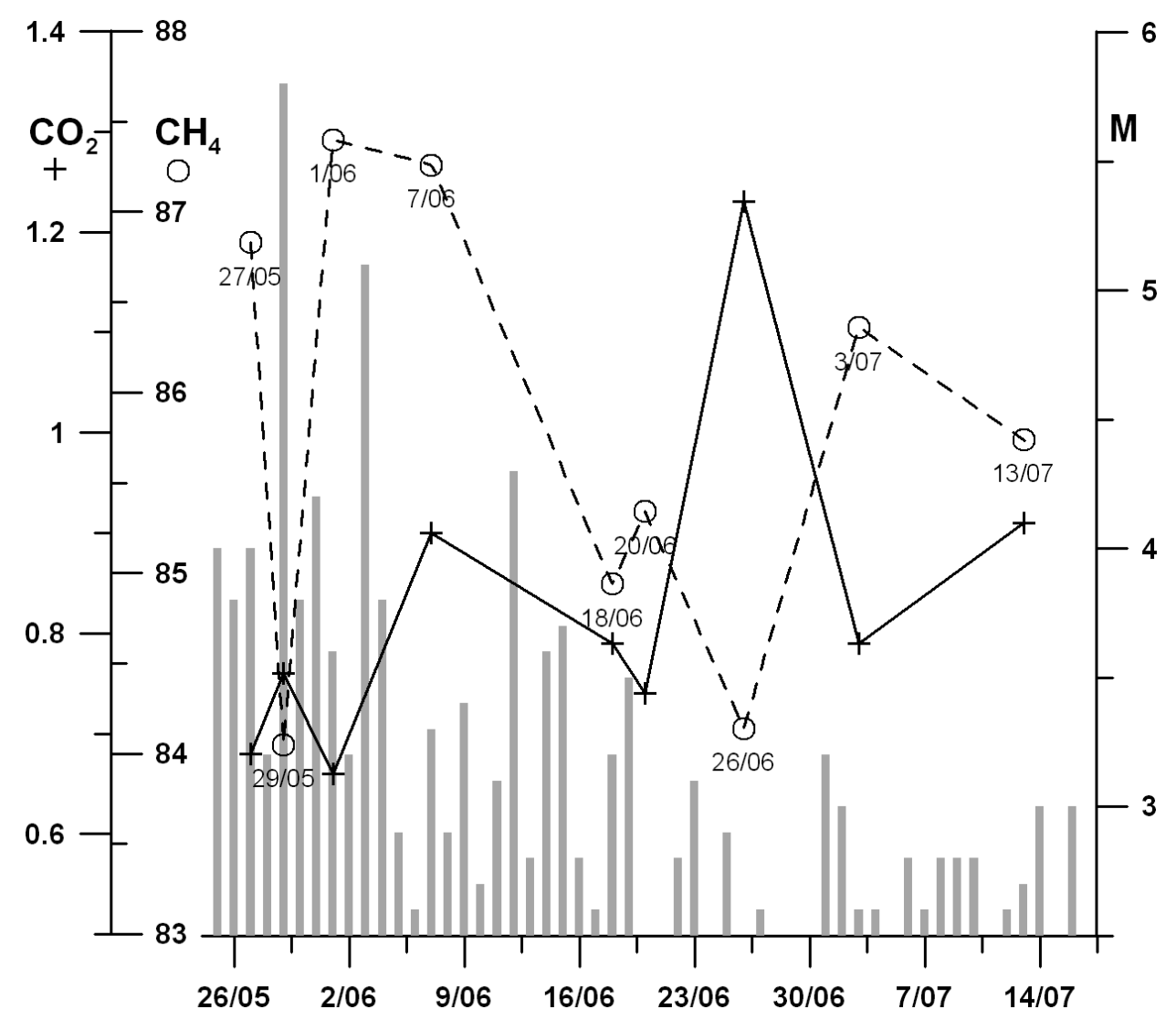

Figure 2. Temporal changes that occurred in the liquid and gas phases. (a) Temporal changes in the calcite saturation state between May 29, 2012, and May 20, 2012. Symbols as in Figure 1a. (b) Temporal changes recorded in the gas phase (bubbling gases of the 1,725-m-deep Vallalta borehole). Variations in $\mathrm{CO}_{2}$ and $\mathrm{CH}_{4}$ concentration (vol\%) with respect to the seismicity of the area (bar chart based on ISIDE-INGV data). Crosses, $\mathrm{CO}_{2}$; empty circles, $\mathrm{CH}_{4}$. The May 29, 2012, M 5.8 event occurred in coincidence with the main changes recorded in the chemical compositions of the vented gases. The inverse correlation shown by $\mathrm{CO}_{2}$ (solid line) and $\mathrm{CH}_{4}$ (dashed line) is of note.

conditions (Figure 2a). This can be attributed to calcite dissolution in contact with $\mathrm{CO}_{2}$-charged waters in a closed system, which indicates possible transients of $\mathrm{CO}_{2}$-rich gases. After June 15, the deep component lowered together with the water flow rate observed at the San Felice sul Panaro sampling site.

The only way towards the contemporary generation of both groundwater chemical anomalies and gaseous anom- alies is the existence of faults that cross the Quaternary and Mio-Pliocenic deep layers. This hypothesis is supported by the preliminary data on gas and water geochemistry changes.

Longer time series are required to confirm the proposed model of fluid/fault relationships. Further investigations will better highlight possible contributions of pre-Miocenic groundwaters hosted in carbonate reservoirs. 


\section{Conclusions}

This geochemical prospection and the periodic sampling of both liquid and gaseous phases in selected groundwaters of the southern Po Valley have revealed the occurrence of tectonic discontinuities that can allow the fast uprising of deep-seated fluids. The fluids are of deep origin and their movement towards the surface is enhanced during seismic sequences. The lowering with time of the main deep-originated components of the gaseous and water phases followed the lowering of the seismic rate and magnitudes. Further sampling will allow a better description of the ongoing tectonic process.

Acknowledgements. The authors wish to thank Prof. G. Yuce and Prof. G. Bianchini for their useful comments and suggestions. The authors are indebted to Giovanni Martinelli who carried out the field work at his own expense. Fausto Grassa, Igor Oliveri, Aldo Sollami, Mariano Tantillo and Francesco Salerno from INGV-Palermo are acknowledged for their contributions to the analytical work.

\section{References}

AGIP Mineraria (1977). Temperature sotterranee. Inventario dei dati raccolti dall'AGIP durante la ricerca e la produzione di idrocarburi in Italia, San Donato Milanese (Milano), $1390 \mathrm{pp}$.

Albarello, D., and G. Martinelli (1994). Piezometric levels as possible geodynamic indicators: analysis of the data from a regional deep waters monitoring network in northern Italy, Geophys. Res. Lett., 21, 1955-1958.

Boccaletti, M., G. Corti and L. Martelli (2011). Recent and active tectonics of the external zone of the northern Apennines (Italy), Int. J. Earth Sci., 100, 1331-1348.

Cenni, N., E. Mantovani, P. Baldi and M. Viti (2012). Present kinematics of central and northern Italy from continuous GPS measurements, J. Geodyn., 58, 62-72.

Conti, A., E. Sacchi, M. Chiarle, G. Martinelli and G.M. Zuppi (2000). Geochemistry of the formation waters in the Po Plain (northern Italy): an overview, Appl. Geochem., 15, 51-65.

Dondi, L., F. Mostardini and A. Rizzini (1982). Evoluzione sedimentaria e paleogeografica nella Pianura Padana, In: G. Cremonini and F. Ricci Lucchi (eds.), Guida alla geologia del margine appenninico-padano, Guida Geologica Regionale, S.G.I, Bologna, 47-58.

Gorgoni, C., and G. Tosatti (2004). Emissioni di metano e fanghi salmastri da un pozzo dismesso in Comune di Concordia sulla Secchia (Provincia di Modena), Atti della Società dei Naturalisti e Matematici Modenesi, 135, 155-174.

Italiano, F., G. Martinelli and A. Rizzo (2004). Geochemical evidence of seismogenic-induced anomalies in the dissolved gases of thermal waters: a case study of Umbria (central Apennines, Italy) both during and after the 19971998 seismic swarm, G-Cubed, 5, 11; doi:10.1029/2004 GC000720.
Italiano, F., P. Bonfanti, M. Ditta, R. Petrini and F. Slejko (2009). Helium and carbon isotopes in the dissolved gases of Friuli region (northeastern Italy): geochemical evidence of $\mathrm{CO}_{2}$ production and degassing over a seismically active area, Chem. Geol., 266, 76-85; doi:10.1016/j. chemgeo.2009.05.022.

Longinelli, A., and E. Selmo (2003). Isotopic composition of precipitation in Italy: a first overall map, J. Hydrol., 270, 75-88.

Martinelli, G., A. Minissale and C. Verrucchi (1998). Geochemistry of heavily exploited aquifers in the Emilia-Romagna region (Po Valley, northern Italy), Environ. Geol., 36, 195-206.

Ori, G.G. (1993). Continental depositional systems of the Quaternary of the Po Plain (northern Italy), Sediment. Geol., 83, 1-14.

Pieri, M., and G. Groppi (1981). Subsurface geological structure of the Po Plain (Italy), CNR, Progetto Finalizzato Geodinamica, 414, 1-13.

Regione Emilia-Romagna and ENI-AGIP (1998). Riserve idriche sotterranee della Regione Emilia-Romagna, G.M. Di Dio (ed.), S.EL.CA., Firenze.

\footnotetext{
${ }^{\star}$ Corresponding author: Francesco Italiano, Istituto Nazionale di Geofisica e Vulcanologia, Sezione di Palermo, Palermo, Italy; email: f.italiano@pa.ingv.it.

C 2012 by the Istituto Nazionale di Geofisica e Vulcanologia. All rights reserved.
} 